\title{
Aktualisasi Kasih Allah bagi Sesama: Implementasi Pemikiran dan Praktik Pendidikan Kristiani Johann Heinrich Pestalozzi dalam Konteks Pendidikan Karakter dan Nilai
}

\author{
Sherly Ribkah Adipati1, Maria Evvy Yanti2* \\ 1,2Sekolah Tinggi Teologi Iman Jakarta \\ *meykalibato@gmail.com
}

\begin{tabular}{l} 
Article History \\
Received: \\
03 April 2021 \\
Revised: \\
12 Mei 2021 \\
Accepted: \\
29 Mei 2021 \\
\hline \\
Keywords \\
(Kata kunci): \\
Christian education; \\
character \\
education; \\
God's love; \\
Johann Heinrich \\
Pestalozzi; \\
values; \\
kasih Allah; \\
nilai; \\
pendidikan \\
Kristiani; \\
pendidikan \\
karakter \\
\\
Dol: \\
http://dx.doi.org/10. \\
33991/epigraphe.v5i1.242 \\
\hline
\end{tabular}

\section{Abstract}

Education is sometimes understood as an attempt to share knowledge only. Students are only prepared to achieve the future in material aspects without realizing the importance of sharing life with others through good behavior. Knowledge and skills as well as knowing and feeling God's presence in life together in the family, school, church, and community need to be paid attention to and practiced. One of the participations is related to this view by rewriting the thoughts of a Christian education expert regarding the concepts and methods of learning in the implementation of education. This article discusses the participation of Johann Heinrich Pestalozzi in Christian education learning, with the aim of preparing and developing basic theological and psychological concepts so that the nature and objectives of learning are implemented in their context. The research method is qualitative with research procedures that make use of descriptive data. After going through a critical study, the results of this article are used as a rationale in practicing Christian education learning for the lives of the people.

\begin{abstract}
Abstrak
Pendidikan terkadang dipahami sebagai usaha untuk membagikan pengetahuan saja. Peserta didik hanya dipersiapkan untuk mencapai masa depan dalam aspek materi saja tanpa kesadaran pentingnya hidup berbagi dengan sesama melalui perilaku yang baik. Pengetahuan dan keterampilan serta mengenal dan merasakan kehadiran Allah dalam kehidupan bersama baik di keluarga, sekolah, gereja dan masyarakat perlu diperhatikan dan dipraktikkan. Salah satu partisipasi yang dilakukan berhubungan dengan pandangan ini dengan menuliskan kembali pemikiran seorang ahli pendidikan Kristiani mengenai konsep dan metode pembelajaran dalam pelaksanaan pendidikan. Artikel ini untuk membahas partisipasi Johann Heinrich Pestalozzi dalam pembelajaran pendidikan Kristiani, dengan tujuan mempersiapkan dan membangun konsep dasar teologis dan psikologis, sehingga hakikat dan tujuan pembelajaran terimplementasi dalam konteksnya. Metode penelitian adalah kualitatif dengan prosedur riset yang memanfaatkan data deskriptif. Setelah melalui kajian kritis, hasil dari artikel ini digunakan sebagai dasar pemikiran dalam mempraktikkan pembelajaran pendidikan Kristiani bagi kehidupan umat.
\end{abstract}

\section{Pendahuluan}

Manusia merupakan makhluk bermoral yang dapat mengalami kegagalan saat melakukan tindakan dalam kehidupan pribadi dan hubungannya dengan sesama. Kondisi tersebut disebabkan oleh kegagalan untuk mendengarkan hati nurani yang benar dan tidak percaya kepada Allah. ${ }^{1}$ Di balik kegagalannya, manusia dengan tugasnya masing-masing memiliki derajat yang

${ }^{1}$ Frederick Eby, The Development, 458. Lihat Fredalene B Bowers and Thom Gehring, Johann Heinrich Pestalozzi: 18 th Century Swiss Educator and Correctional Reformer' 
sama di bawah otoritas Allah. Mereka berhak untuk mendapatkan kemerdekaan atas hidupnya dan melaksanakan kebaikan bagi diri dan sesamanya yang dibangun atas dasar kasih dan moralitas.

Penelitian yang dilakukan Thomas Lickona menggambarkan situasi jaman dengan penjelasannya, bahwa orang-orang pada masa ini demikian cerdasnya dalam membedakan hal yang benar dan salah, namun demikian ia tetap memilih untuk melakukan yang salah. ${ }^{2}$ Situasi jaman berhadapan dengan kasus-kasus kekerasan yang dilakukan generasi penerus bangsa. Hal ini menyebabkan teradinya kehancuran nilai-nilai moral dan merebaknya ketidakadilan. Berbagai fenomena tersebut dapat merembes kedalam bidang-bidang kehidupan salah satunya pendidikan. Kurangnya perhatian pada nilai-nilai moral dan religius dalam Pendidikan yang dipraktikkan di sekolah-sekolah berpengaruh pada masa depan peserta didik dan pembentukan karakter kemanusiaannya.

Kemajuan ilmu pengetahuan yang pesat haruslah diimbangi dengan sistem pendidikan yang mengabdikan pada kesejahteraan bersama melalui pengembangan moral dan religius. Apabila tidak disertai dengan sikap yang bijak dalam menanggapi situasi ini, bisa saja terjadi pergeseran paradigma keyakinan kehidupan manusia yang bertuhankan pada pengetahuan. Kehidupan manusia menjadi kehilangan integritas karena segala sesuatu akan ditentukan oleh pengetahuan dan mengarah pada pola kehidupan hedonisme dan materialisme. ${ }^{3}$ Seharusnya kemajuan pengetahuan lebih mengarah pada penghayatan manusia kepada otoritas Allah melalui pengembangan diri secara utuh, berbagai macam dimensi yang dimilikinya yaitu: religius, moral, personal, sosial, kultural, institusional dan relasional.

Pendidikan Kristiani (selanjutnya ditulis PK) selain sebagai pengajaran ilmu pengetahuan, dipahami sebagai proses penanaman ajaran dan nilai-nilai Kristiani yang bertujuan mengubah dan memperbaiki kualitas hidup manusia dalam arti yang seluas-luasnya. Hal ini mengundang pertanyaan bagaimana peran pendidikan yang terus berkembang dalam sisi kemanusiaan melalui proses belajar yang dilaluinya bukan hanya sekedar mempersiapkan masa depan, hidup berkelimpahan, berhasil dalam karier dan memiliki jabatan yang tinggi. Bagaimana tercipta proses belajar dan pendidikan yang menciptakan manusia yang dapat menghargai hidupnya sebagai anugerah Allah, menggunakan setiap kesempatan atau waktu hidupnya dengan bertanggung jawab kepada Allah dan sesama serta dapat berbagi kasih dalam kehidupan mereka.

Salah satu usaha untuk menjawab pertanyaan ini akan diuraikan mengenai sumbangan pemikiran seorang ahli (PAK) Johann Heinrich Pestalozzi yang mendedikasikan hidupnya melalui pendidikan dan pengajaran kepada peserta didik berdasarkan tinjauan teologis dan psikologis yang terimplementasi melalui pemikiran dan praktik PAK berdasarkan konteksnya. Frederick Eby menuliskannya mengenai Pestalozzi sebagai berikut, "Pestalozzi as a philanthropic educator of Zurich, has exerted the greater influence upon modern society. "4

Johann Heinrich Pestalozzi memiliki panggilan hidup untuk mengembangkan kegiatan pendidikan bagi anak-anak miskin. Ia adalah seorang yang mengabdikan seluruh hidup, pikiran dan kemampuannya untuk memperbaiki keadaan buruk dalam masyarakat. Pembaruannya dilakukan melalui pendidikan yang yang bukan hanya memberi pengetahuan saja, tetapi memper-

\footnotetext{
2 Thomas Lickona, The Return of Character Education, Jurnal Education Leadership (1993), 35.

${ }^{3}$ H.A.R. Tilaar, 50 Tahun Pembangunan Pendidikan Nasional 1945-1995 (Jakarta:Grasindo, 1995), 619.

${ }^{4}$ Frederick Eby, The Development of Modern Education 2 ed (New Delhi: Prentice-Hal of India PVT.LTD, 1964), 431.
} 
hatikan dan mengembangkan pendidikan bagi anak-anak miskin yang tidak dihiraukan oleh kaum atas. Ia tertarik pada perbaikan pendidikan secara lahiriah dan batiniah untuk membimbing mereka memiliki gaya hidup bermoral. Selain itu untuk menciptakan komunitas pendidikan yang bersifat kekeluargaan dalam suasana saling berbagi dalam anugerah Allah sebagai aktualisasi kasih-Nya kepada sesama.

Berpijak pada fenomena yang telah dituliskan maka penulis merasa perlu melakukan pengkajian landasan teori praktik dari tujuan PK Johann Heinrich Pestalozzi secara umum yang diarahkan untuk menghasilkan seorang yang bijaksana dan bajik dalam kehidupannya, manusiawi dalam semua hubungan dengan sesamanya dan hidup beriman sebagai makhluk yang bergantung pada Allah. Selain itu penulis juga meneliti tujuan khusus yang dipraktikkan dalam pengajaran PK Johann Heinrich Pestalozzi. Tujuan khusus ini dapat diaktualisasikan melalui Pendidikan karakter dan nilai. Kedua aspek ini memberikan kesadaran bagi siswa untuk menempatkan dirinya dalam hubungan dengan sesama melalui wawasan kedalaman nilai-nilai moral. Pendidikan karakter dan nilai-nilai moral secara tidak langsung dan disadari sudah dilakukan serta dialami oleh setiap manusia sepanjang kehidupannya.

\section{Metode}

Metode penelitian dalam tulisan ini adalah penelitian kualitatif yang dipahami sebagai prosedur riset dengan memanfaatkan data deskriptif, berupa data teori tertulis yang dapat diamati. Penelitian kualitatif dilakukan untuk menjelaskan dan menganalisis fenomena, peristiwa, dinamika sosial, sikap kepercayaan, dan persepsi seseorang terhadap sesuatu. Maka, proses penelitian kualitatif dimulai dengan menyusun asumsi dasar dan aturan berpikir yang akan digunakan dalam penelitian. Kemudian pengalaman sosio-kultural manusia yang dibentuk untuk mendapatkan makna sehingga objek penelitian kualitatif meliputi seluruh aspek atau bidang kehidupan manusia, yaitu manusia dan segala sesuatu yang dipengaruhi olehnya.

\section{Pembahasan}

Pola pendidikan yang menempatkan ketaatan kepada Allah adalah pendidikan yang tidak hanya menekankan sisi kognitif menghasilkan manusia yang berkualitas secara ilmu. Tetapi menjadi individu yang berperilaku benar di hadapan Allah yaitu mengasihi Allah dan sesama secara bertanggung jawab. Praktik pendidikan yang berada di bawah otoritas Allah akan menciptakan pola kehidupan yang berkeadilan bagi semua masyarakat. ${ }^{5}$ Rasa humanis yang dinyatakan melalui kesadaran akan keberagaman manusia merupakan nilai rasa yang menjunjung tinggi pada otoritas Allah sebagai pencipta. ${ }^{6}$ Kesadaran ini akan bertumbuh atas dasar jalinan relasi yang benar dengan Allah dan sesama. Konsep ini akan menciptakan sistem pendidikan yang membebaskan manusia dari bentuk penindasan dalam pendidikan. Pendidikan yang membebaskan adalah pendidikan yang mengembangkan rasa tanggung jawab sebagai warga negara untuk mewujudkan masyarakat yang damai dan berkeadilan. ${ }^{7}$ Demikian pula pendidikan diupa-

\footnotetext{
${ }^{5}$ H.A.R Tilaar dan Rianto Nugroho, Kebijakan Pendidikan (Yogyakarta:Pustaka Pelajar, 2008), 30.

${ }^{6}$ Bdk. Serva Tuju et al., "Hospitalitas Pendidikan Kristiani Dalam Masyarakat Majemuk," Jurnal Teologi Berita Hidup 3, no. 2 (2021): 328-339.

${ }^{7}$ H.A.R Tilaar Perubahan Sosial dan Pendidikan: Pengantar Pedagogik Transformatif untuk Indonesia (Jakarta:Grasindo, 2002), 203.
} 
yakan untuk bersahabat dan berpihak pada kaum miskin sehingga mereka memperoleh kesempatan untuk belajar dan mengembangkan dirinya. ${ }^{8}$

Pelaksanaan pendidikan Kristiani membantu anak didik mengembangkan semua segi kemanusiaannya seperti aspek kognitif, sosial, moral dan spiritual. Pandangan ini mengarahkan anak didik untuk dapat memahami aspek-aspek kehidupan sebagai ciptaan yang menghargai Tuhan dan ciptaan-Nya. ${ }^{9}$ Sehingga praktik pendidikan Kristen memiliki tujuan untuk membangun anak didik supaya dapat mengembangkan iman dan pengetahuannya berdasarkan Firman Tuhan dalam kehidupan mereka sehari-hari. ${ }^{10}$

\section{Dasar Teologis}

Pandangan praktik PAK Pestalozzi didasari oleh penghayatannya berasarkan kepercayaannya kepada Allah dinyatakan melalui kasih kepada Allah dan sesama yang merupakan aktualisasi hukum kasih dalam Markus 12:29-31. Pestalozzi mempercayai dan mengenal Allah yang nyata dalam hidupnya yang menjadi dasar terciptanya hubungan harmonis di antara keduanya dan di antara sesama manusia. Pendidikan bagi umat manusia merupakan suatu jalinan aktualisasi kasih kepada Allah dan sesama. Mengasihi Allah dapat dinyatakan melalui kepedulian untuk mendatangkan kebahagiaan bagi sesama.

Teladan Yesus menjadi nafas hidup Pestalozzi yang memengaruhi cara berpikir dan tercermin dalam hubungan dengan sesamanya. Ia memperlakukan sesamanya tanpa membedakan karena ia berpendapat bahwa semua orang berdiri di atas tanah dan hidup bersama-sama. Pestalozzi memandang pada kesamaan status di antara manusia. Mereka memiliki struktur jasmani yang sama, lahir dan berkembang menurut proses yang sama sehingga tidak ada alasan mereka dibedakan atas beberapa golongan sosial. Semua manusia memiliki hak yang sama atas alam ciptaan Allah. Mereka berhak untuk mendapatkan pengetahuan yang berasal dari alam melalui proses pendidikan yang dapat menolong mereka memperoleh manfaat dari alam.

\section{Dasar Psikologis}

Pestalozzi melakukan penelitian tentang kelakuan anak-anak berdasarkan pengalaman hidupnya bersama dengan mereka di dalam kelas. Ia mencoba untuk memahami proses perkembangan anak-anak dengan menyelidiki keberadaan mereka. Ia memulai penelitiannya melalui alam yang dapat membuka rahasia perkembangan anak. Proses perkembangan belajar mengajar terjadi seiring dengan proses pertumbuhan alamiah diawali dengan penerapan hal-hal praktis, mengadakan pengujian lalu dirumuskan kesimpulan umum untuk menetapkan langkah selanjutnya.

Asas-asas belajar mengajar yang dipraktikkan Pestalozzi melalui usaha membangun pengetahuan yang sudah ada dalam diri anak. Tahap pertama mereka diajar untuk menyelesaikan halhal sederhana sebelum menuju ke yang majemuk. Anak-anak diajar untuk dapat memahami materi pelajaran yang sederhana sebelum beranjak kepada pelajaran yang lebih sulit. Tahap kedua anak-anak diberikan materi pelajaran yang terfokus pada salah satu jenis materi saja, sehingga pemahaman mereka tidak meluas pada materi pelajaran lain yang tidak berhubungan. Tahap ketiga anak-anak didik diarahkan untuk belajar melalui proses pengalaman pancaindera. ${ }^{11}$

\footnotetext{
${ }^{8}$ Ferawati, “Krisis Pendidikan: Peluang Pendidikan Kristen Bermisi bagi Transformasi Bangsa” diakses dari http://perkantasjatim.org, tanggal 17 Maret 2021.

${ }^{9}$ Paul Suparno, Pendidikan Nilai di Sekolah dan Persoalannya, 310.

${ }^{10}$ Poerwodidagdo Judowibowo, Pendidikan Hak Asasi Manusia dalam Pendidikan Agama Kristen, dalam Ajar Mereka Melakukan (Jakarta: BPK Gunung Mulia, 2003), 112-113.

${ }^{11}$ Donald Clark, Pestalozzi and Pestalozzianism , didapat dari http:// dipergunakan 13 Maret 2021
} 
Mereka diberi kesempatan untuk berinteraksi langsung dengan objek yang akan dipelajarinya. Tahap keempat pengetahuan melalui pancaindera bertujuan untuk mendapatkan pengetahuan tentang jumlah, bentuk dan bahasa.

Pengetahuan yang disampaikan kepada anak didik dikelompokkan berdasarkan kesamaan sifatnya sehingga memudahkan mereka untuk memahami hubungan-hubungan yang berlaku di antara beberapa objek. Anak didik dapat diarahkan untuk melihat persamaan dari beberapa gagasan objek yang berbeda sebelum merumuskan kesimpulan. ${ }^{12}$ Sehingga menjauhkan mereka dari pandangan yang dogmatis dan memiliki kecenderungan memutlakkan suatu pandangan.

Berlakunya hukum-hukum alam sebagai pengetahuan bagi anak didik tidak menghambat mereka untuk bertumbuh dalam proses belajar. Hukum-hukum alam yang dipelajari tidak dapat memenuhi kebutuhan manusia secara utuh. Perkembangan manusia memerlukan hukum kehidupan moral dan rohani untuk mencapai tujuan dari pengalaman pendidikan yaitu menghasilkan manusia yang benar. ${ }^{13}$ Pestalozzi berminat mengembangkan pokok iman anak didik dalam bidang pendidikan. Pertumbuhan iman anak didik merupakan hasil dari pengalaman kasih. Pandangan tersebut menyatakan bahwa Pestalozzi menegaskan kasih yang telah dinyatakan kepada anak-anak adalah pondasi untuk mereka melakukan pekerjaan. Tanpa kasih kekuatankekuatan intelektual tidak berkembang secara alami. Pestalozzi bertindak sebagai orang tua dari anak-anak yang dididiknya sehingga mereka merasakan berada dalam lingkungan kasih yang nyata. Ia menyatakan ingin mengarahkan pendidikan pada kekuatan alamiah yang dimiliki manusia dan diterangi oleh Allah sehingga terpelihara di dalam hati para orang tua dan mereka akan tumbuh dalam kasih kepada Allah dan manusia. ${ }^{14}$

Pengenalan kepada Allah mulai diberikan kepada anak didik untuk menanamkan perkembangan moral dan rohani mereka. Allah yang penuh kasih dipahami hadir dalam setiap fenomena alam kehidupan manusia. Pendidikan yang penuh dengan kasih mendorong anak didik untuk bersemangat belajar sehingga tercipta suasana yang menumbuhkan pengetahuan, semangat dan kasih. Ia mengembangkan suatu roh dalam bidang pendidikan baru, yaitu menanamkan kasih yang tulus kepada anak-anak. ${ }^{15}$

\section{Hakikat Pendidikan Kristiani dalam Keluarga}

Pestalozzi adalah seorang pendidik yang belajar dari pengalaman mengajar di dalam kelas. Teori dibangun berdasarkan praktik dan mengalami perbaikan-perbaikan ketika dipraktikkan kembali. Menurutnya pendidikan Kristiani melibatkan kekuatan alam dan pancaindera tiap-tiap manusia. Melalui pendekatan praktik dan teori dalam pendidikan, ia menyatakan arti PK sebagai suatu usaha untuk memperlengkapi kemampuan anak-anak didik dengan memerhatikan kebutuhan dasar dimana mereka hidup. Pestalozzi menuliskan ada tiga konteks PK yang saling berhubungan. Adapun konteks PK itu adalah keluarga atau rumah tangga Kristen.

Terciptanya suasana kasih dan ketertiban dalam rumah tangga dapat mendukung terlaksananya PK bagi anggota-anggota keluarga. Kasih sayang orang tua yang dilandasi dengan ketulusan dapat membangun kepercayaan dalam diri anak-anak. Melalui roman karyanya yang berjudul Lienhard und Gertrud, Pestalozzi menggambarkan tentang pentingnya lingkungan

\footnotetext{
12 Kate Silber, Psetalozzi The Man and His Work, 140.

${ }^{13}$ Frederick Eby, The Development of Modern Education, 439

${ }^{14}$ Kate Silber, Pestalozzi The Man and His Work, 134.

${ }^{15}$ Mark K. Smith, Johann Heinrich Pestalozzi, Encyclopedy on line: didapat dari http// dipergunakan 24 Maret 2021
} 
rumah tangga sebagai lingkungan yang paling wajar dalam pelaksanaan PK. Dalam lingkungan rumah tangga yang baik anak-anak dapat belajar tentang kerukunan hidup, menaati peraturan yang berlaku dalam rumah tangga, mendapatkan pengetahuan dan keterampilan serta mereka mengenal Allah dan merasakan kehadiran-Nya dalam kehidupan bersama di tengah-tengah keluarga.

Kehidupan rumat tangga (keluarga) menumbuhkan pendidikan karakter dan nilai anak yang merupakan tanggung jawab utama orang tua. Mereka berperilaku sebagai agen pendidikan moral dan nilai hidup bagi anak-anak, sehingga gereja perlu memberikan perhatian pada pertumbuhan karakter keluarga-keluarga tersebut. Keluarga mempengaruhi pembentukan watak, iman dan tata nilai anak-anaknya. Keluarga merupakan lingkungan primer dalam membentuk kecerdasan moral anak. ${ }^{16}$ Sebelum anak menerima pengaruh dari teman sebaya dan guru di sekolah, ia sudah mendapat pengaruh dari keluarganya.

Terdapat hal-hal yang penting mengenai pertumbuhan anak dalam keluarga, yaitu: kasih, disiplin, konsistensi aturan, keteladanan, kepemimpinan. ${ }^{17}$ Melalui uraian tersebut dikemukakan bahwa karakter, tata nilai, potensi dan cara beriman tercipta dan berkembang dari keluarga asal tempat anak didik bertumbuh. Dalam keluarga pendidikan nilai-nilai Kristiani dapat dipraktikkan. Ada banyak cara dapat dikembangkan orang tua dan komunitas keluarga untuk menanamkan nilai-nilai tersebut kepada anak. Orang tua dengan sadar menjadikan dirinya teladan moral dalam mendemonstrasikan nilai hidup dan karakter yang baik dan benar untuk diteladani anak-anak. Orang tua dapat memberi latihan-latihan untuk terus berbuat baik disertai hukuman dan pujian yang seimbang. Orang tua dapat memberikan penjelasan melalui nasihat dan diskusi untuk memberi informasi kepada anak. Orang tua memelihara kedekatan dengan anak supaya mereka dapat mengidenfikasi dirinya. Orang tua dapat membangun persahabatan dengan saudara di lingkungan keluarga dan teman-teman di luar rumah tempat anak belajar dari sesamanya.

Keluarga, khususnya orang tua, memiliki tugas untuk mendidik anak-anaknya bertumbuh dalam nilai-nilai kerohanian kepada Allah dalam Yesus Kristus. Orang tua adalah tokoh terdekat bagi anak yang Allah kehendaki menjadi pembentuk generasi penerus. Kasih, kesetiaan, dan kesediaan belajar terus menerus itulah yang sangat diperlukan. Keluarga secara teologis disebut sebagai miniatur gereja suatu komunitas yang mengemban misi panggilan Allah untuk menyatakan kasih dan kebenaran-Nya. ${ }^{18}$ Keluarga memiliki tanggung jawab untuk membimbing anak-anaknya dalam menentukan sikap sesuai dengan nilai-nilai kebenaran Allah. Keluarga menjadi tempat ditaburnya nilai-nilai ketaatan, ketekunan, pengendalian diri, kepeduliaan, kejujuran dan tuntunan Allah.

Pestalozzi menuliskan beberapa pengajar dalam praktik PK yang memberikan pengaruh besar bagi keberhasilan pelaksanaan pendidikan. Kehidupan Pestalozzi tidak mengatakan bahwa hanya ibu yang dapat melakukan proses pendidikan bagi anak-anaknya. Ia memuji peranan seorang ibu sebagai pengajar bagi anak-anaknya dalam keluarga. Ibu dapat menolong anakanaknya untuk mengamati pelbagai objek yang ada dalam suatu rumah tangga. Seorang ibu dapat mengarahkan anak-anaknya untuk memiliki pola pikir bahwa segala sesuatu disebabkan

\footnotetext{
${ }^{16}$ Robert Coles, Menumbuhkan Kecerdasan Moral Pada Anak (Jakarta:Gramedia Pustaka Utama, 2000), 38.

${ }^{17}$ Paul Meier, Christian Child Rearing and Personality Development (NewYork :Baker Book House, 1980), 81.

${ }^{18}$ Marjorie L. Thompson, Keluarga Sebagai Pusat Pembentukan: Sebuah Visi tentang Peran Keluarga dalam Pembentukan Rohani (Jakarta:BPK GM, 2000), 24.
} 
oleh sesuatu yang lain serta membimbing anak-anaknya untuk mengenal Allah. Penyebutan nama Tuhan dengan rasa hormat di hadapan anak-anaknya dapat menumbuhkan pengenalan yang baik dan hormat serta belajar untuk mengasihi Tuhan dengan segenap hati, jiwa, kekuatannya dan akal budinya.

Selain ibu, guru adalah pengajar bagi anak-anak setelah ibu mereka dalam keluarga. Peranan seorang guru dapat menentukan keberhasilan dan kegagalan pendidikan anak-anak. Pestalozzi menggambarkan Guru-guru Kristen yang dimaksud meliputi guru-guru Sekolah Minggu dan guru-guru Pendidikan Agama Kristen di sekolah. Mereka memiliki peranan dalam pembentukan dan pertumbuhan spiritual anak melalui praktik nilai-nilai Kristiani. Mereka merupakan rekan kerja orang tua dalam mendidik dan mengajar anak-anak. Salah satu keterampilan emosi dasar yang dimiliki guru meliputi pengajaran mengenai pengenalan perasaan dan memberikan label pada setiap emosi yang dirasakan. Hal ini penting untuk menyadari adanya hubungan antara pikiran, perasaan dan tindakan. Seorang guru dapat membimbing anak didiknya untuk mengenali perasaan-perasaannya dalam berbagai situasi serta memahami bagaimana munculnya berbagai perasaan tersebut. Pada bagian ini seorang guru mengajarkan dan memberikan contoh bagaimana mencari cara untuk mengendalikan emosi. Mengarahkan perasaan takut, cemas dan sedih menjadi sesuatu yang positif dalam hidup mereka.

Guru bukan hanya mengajar dan menghasilkan orang yang suci dan alim tetapi dengan pengetahuan yang rendah. Pengajaran pengetahuan didasari dengan pembentukan sikap menghargai orang lain walaupun berbeda pendapat, saling mempercayai keterampilan sosial, saling mengampuni, dan membantu peserta didik untuk memiliki ketaatan kepada kehendak Allah. Pembinaan dan penanaman karakter yang dikehendaki Allah harus benar-benar dilakukan. ${ }^{19}$

Guru yang baik adalah ia yang dipenuhi oleh roh kasih, hikmat, dapat dipercaya serta memberikan pengajaran bagi anak-anak didik untuk memperoleh keterampilan. Ia disukai oleh orang tua dan anak didiknya karena apa yang telah dilakukannya bagi mereka. Orang tua merasa bahagia karena guru yang baik telah berhasil membantu anak-anaknya memperoleh pendidikan yang bermutu, memiliki keterampilan yang berguna bagi masa depan anak-anak didik, sekaligus juga dapat memperbaiki mutu kehidupan masyarakat di desa-desa. Usaha untuk menggali dan menemukan bakat yang tersembunyi dalam diri anak-anak didiknya terus dilakukan melalui pengembangan kegiatan belajar sesuai dengan bakat yang dimiliki mereka. Guru yang baik memiliki rasa kepedulian yang besar, mampu berempati, rela berkorban bagi anak-anaknya.

Seorang anak dapat menjadi pengajar bagi teman-temannya ketika mereka mengalami kesulitan memahami mata pelajaran yang dipelajarinya. Mereka dapat saling menolong untuk memahami mata pelajaran tersebut sehingga mereka tidak hanya menjadi murid yang hanya menerima bimbingan tetapi juga membimbing temannya yang lain. Pestalozzi berpendapat bahwa sangatlah penting untuk mengutamakan perhatian pada pemikiran anak didik. Setiap anak didik dibimbing untuk terbiasa memahami setiap pengetahuan yang diajarkan untuk dapat mencari perbandingan dan mempertimbangkan setiap pengetahuan. Hal ini dipraktikkan supaya anak tidak terjebak dalam konsep indoktrinasi.

Relasi antar pribadi dibutuhkan dalam praktik pendidikan karakter sebagai suatu perjumpaan yang saling memperkaya dan menumbuhkan setiap individu dengan latar belakang yang

\footnotetext{
${ }^{19}$ Samuel Karwur,'Pendidikan Kristen:Kritis!", diakses dari http:/blog.charismaindonesia.com, tanggal 16 Maret 2021
} 
berbeda. Perbedaan ini dipengaruhi oleh komunitas dimana individu-individu itu berada yang menciptakan nilai-nilai yang berbeda pula. Melalui pendidikan karakter keberagaman pemahaman tersebut diarahkan untuk memperoleh pemahaman yang lebih jelas akan praktik nilai-nilai yang terkandung. Hal ini akan menciptakan individu-individu yang mengabdikan dirinya dengan penuh integritas untuk hidup sesuai dengan nilai-nilai yang diyakininya itu. Arah pendidikan karakter dalam komunitas masyarakat dan jemaat khususnya mewujudkan individu-individu yang kualitas yang tinggi dalam kompetensi serta praktik moral dan nilai hidup yang sesuai dengan kehendak Allah.

Pestalozzi memberikan pelajaran umum kepada setiap anak tanpa membedakan keadaan mereka. Pelajaran umum yang diajarkan berdasarkan pengalaman hidup mereka. Materi yang diajarkan bertujuan untuk mengantisipasi setiap kondisi yang mereka hadapi untuk dapat mencari solusi berdasarkan pengetahuan yang dimilikinya. Materi-materi pelajaran khusus juga diajarkan sesuai dengan bakat anak-anak didik. Upaya mengembangkan bakat dapat dilakukan oleh mereka sendiri dengan memperhatikan setiap hal yang terjadi dalam pengalaman hidupnya. Pestalozzi hendak mengatakan bahwa pengalaman pendidikan tidak hanya dapat diperoleh dari sekolah dan rumah tetapi dari pengalaman hidup yang mereka alami.

\section{Refleksi Teologis dan Pedagogis PAK}

Pestalozzi terpanggil untuk memperhatikan, memberikan dan mengembangkan pendidikan bagi semua anak-anak tanpa membeda-bedakan status sosialnya. Setiap anak laki-laki dan perempuan mendapat kesempatan untuk memperoleh pengetahuan. Ia berhasrat untuk menolong anak-anak memperoleh pendidikan supaya terdapat kemungkinan mereka dapat menjalani kehidupan yang lebih baik. Pemikiran Pestalozzi tentang praktik dan teori dalam pendidikan sesuai dengan pandangan Paulo Freire. Pandangan tersebut menegaskan bahwa teori bukanlah sesuatu yang terlepas dari praktik. Setelah melalui pengalaman belajar di kelas maka akan menciptakan teoriteori yang berguna untuk menumbuhkembangkan pendidikan. ${ }^{20}$

Kurikulum Pestalozzi yang kontekstual senada dengan pandangan Paul Suparno yang menegaskan bahwa dalam pelaksanaan pendidikan, kurikulum disesuaikan dengan konteks yang ada dan fungsi sekolah yang bersosialisasi di tengah-tengah masyarakat sebagai laboratorium pengembangan nilai-nilai ketulusan dan kejujuran. ${ }^{21}$ Adalah bijaksana jika penyampaian materi pembelajaran kepada anak-anak didik memperhatikan konteks dimana mereka tinggal. Mereka mempunyai hak atas kelangsungan hidup, perlindungan, perkembangan dan mendapatkan pendidikan.

Keteladanan hidup Pestalozzi menjadikan dia sebagai seorang pendidik yang penuh kasih dan selalu menciptakan hubungan persaudaraan di antara para anak didik. Seorang pendidik harus memiliki keteladanan hidup atas dasar kasih sehingga diperlukan ketulusan dalam pendidikan melalui kejujuran dalam menyampaikan pengetahuan yang lebih dialogis atas dasar kasih. Pendidikan yang didasari kasih dapat dilakukan dengan cara menghindari terciptanya kompetisi yang tidak sehat dan tidak akan menciptakan kekerasan bagi anak-anak didik. Pola pendidikan ini akan membentuk karakter anak-anak didik, karakter yang dimiliki manusia meru-

${ }^{20}$ Paulo Freire, Pendidikan, Pembebasan, Perubahan Sosial, terj. Mien Joebbaar (Jakarta: PT Sangkala Pusar, 1984), 43-44.

${ }^{21}$ Paul Suparno, Apakah Pendidikan Menghasilkan Ketulusan, BASIS edisi ketulusan (2000), 64. 
pakan suatu struktur antropologis yang terarah dalam proses penyempurnaan diri manusia secara terus menerus dalam rangka menjawab hal-hal yang menyangkut eksistensinya. ${ }^{22}$

Praktik PK Pestalozi berkenaan dengan pendidikan karakter yang meliputi pendidikan moral dan pendidikan nilai. Pendidikan moral mengarahkan pada pengambilan keputusan moral secara individu dalam hal-hal yang berkenaan dengan apa yang dianggap baik dan tidak baik dalam relasi dengan orang lain. Sementara pendidikan nilai diarahkan pada nilai-nilai yang menjadi pedoman seorang individu dalam kehidupannya. Tujuannya adalah mengaktualisasikan diri dalam nilai-nilai tersebut. Nilai yang dimaksud misalnya nilai kejujuran, nilai kesetiaan, atau nilai kepedulian. Pendidikan karakter melibatkan pendidikan moral dan pendidikan nilai dalam praktiknya. Seorang pendidik baik guru di gereja maupun di sekolah bertanggung jawab supaya anak didiknya mampu mempraktikkan implikasi etis berbagai macam perubahan, mampu mengembangkan nilai-nilai dalam dirinya, serta mampu mengambil keputusan berdasarkan pemahaman yang jelas tentang nilai-nilai tersebut. ${ }^{23}$ Nilai-nilai yang dimiliki oleh setiap individu akan terus dikembangkannya sendiri, namun dalam praksisnya, karakter-karakter yang diharapkan muncul dalam rangka kehidupan bersama hadir sebagai koridor yang membatasi individu dalam kesadarannya akan kebebasannya. ${ }^{24}$

Pendidikan karakter memberikan kesadaran bagi siswa untuk menempatkan dirinya dalam hubungan dengan sesama. Sementara pendidikan nilai dapat memperkaya wawasan anak akan kedalaman nilai-nilai tersebut. Pendidikan karakter secara tidak langsung dan tidak disadari sudah dilakukan dan dialami oleh setiap manusia sepanjang kehidupannya. Nilai-nilai yang umum diakui orang sebagai sesuatu yang luhur, seperti kejujuran dan keadilan sudah berkembang sebelum anak masuk dunia pendidikan dan masyarakatnya. Setiap individu lahir di tengahtengah keluarga dan terdapat penetapan nilai-nilai tertentu menjadi prasyarat tanpa sadar sebagai pembentuk suatu keluarga. Terjadi penetapan kesepakatan nilai-nilai tertentu yang terbentuk dalam suatu keluarga.

\section{Kesimpulan}

Johann Heinrich Pestalozzi mengembangkan model pendidikan yang berdasarkan kasih kepada Allah dan sesama. Hal ini dilakukan melalui peranan para guru yang memiliki kasih dan dinyatakan melalui pendidikan bagi anak-anak didiknya. Suasana pendidikan yang dipenuhi kasih dapat menghasilkan anak-anak didik yang memiliki kepedulian dan mendatangkan kebahagiaan bagi sesamanya. Model pendidikan di sekolah-sekolah menurut Johann Heinrich Pestalozzi perlu memerhatikan pengembangan kemampuan anak-anak didik yang pada akhirnya menjadi keterampilan yang akan mereka miliki. Keterampilan yang mereka miliki dapat menjadi bekal ketika berada di tengah-tengah masyarakat. Anak-anak didik dapat memanfaatkan apa yang ada di tengah-tengah masyarakat. untuk mengembangkan keterampilannya.

Teori dan praktik pendidikan Kristiani Pestalozzi untuk memperbaiki akhlak, memberikan pengetahuan dan memperlengkapi anak-anak didik dengan keterampilan baik. Teori ini dilaksanakan dengan tujuan membebaskan manusia dari belenggu ketidaktahuan, keterbelakangan, keterasingan, keterpurukkan dan kemiskinan. Pendidikan sebagai sarana untuk menuju pada kualitas kehidupan yang lebih baik dengan mempraktikkan karakter mereka. Individu-individu

\footnotetext{
${ }^{22}$ Doni Koesoema A, Pendidikan Karakter, 88

${ }^{23}$ Ibid., 199.

${ }^{24}$ Ibid., 99.
} 
yang berkarakter untuk mengabdikan integritas dirinya sesuai dengan nilai-nilai yang diyakini, kompetensi yang berkualitas, praktik moral dan nilai hidup yang sesuai dengan kehendak Allah.

\section{Referensi}

Boehlke, Robert R. Sejarah Perkembangan Pikiran dan Praktek PAK Jakarta: BPK Gunung Mulia, 1997

Bowers Fredalene B. and Gehring, Thom. Johann Heinrich Pestalozzi: 18 th Century Swiss Educator and Correctional Reformer' didapat dari http://dipergunakan 12 Maret 2021.

Clark, Donald. Pestalozzi and Pestalozzianism, didapat dari http:// dipergunakan 23 Maret 2021

Erikson, The Reformers : An Historical Survey of Pioneer Experiments in The Treatment of Criminals (NewYork : Elsevier, 1976), 108.

Frederick Eby, The Development of Modern Education 2 ed. New Delhi: Prentice-Hal of India PVT.Ltd, 1964

Freire, Paulo. Pendidikan, Pembebasan, Perubahan Sosial, terj. Mien Joebbaar Jakarta: PT Sangkala Pusar, 1984.

H. Holman. Pestalozzi: An Account of His Life and Work, London: Longmans, Gereen and co, 1908.

Heafford, Pestalozzi: His Though and Its Relevance Today, London: Methuen, 1967.

hhtp:// sorot.vivanews.com/, 20 Maret 2021.

http://id.wikipedia.org/wiki/Berkas:Suiceide_rates_map-en.svg, 24 Maret 2021

http://myais.fsktm.um.edu.my/6578/1/JPPSee_(113-129) B.pdf, 26 Maret 2012

Johann Heinrich Pestalozzi, How Gertrude Teaches Her Children, Ed and Prefaces by Daniel Robinson. Washington D.C: University Publications, 1977.

Kate Silber, Pestalozzi: The Man and His Work, London: Routledge and Kegan Paul, 1960.

Koesoema, Doni. 'Pendidikan dan Kekerasan,' Kompas, 11 April 2007.

Mark K. Smith, “Johann Heinrich Pestalozzi” (Encuclopedia on-line) didapat dari http://dipergunakan 3 Maret 2021.

Patty, Albertus. Membangun Pendidikan Kristiani di Era Globalisasi, Pleno BPK PENABUR, 23 Februari 2007,

Shane, Harold G. Arti Pendidikan bagi Masa Depan, Jakarta: CV Rajawali, 1997.

Smith, Mark K. Johann Heinrich Pestalozzi, Encyclopedy on line: didapat dari http// dipergunakan 24 Maret 2014

Suparno,Paul. Apakah Pendidikan Menghasilkan Ketulusan, BASIS edisi ketulusan

Tuju, Serva, Harls Evan R Siahaan, Melkius Ayok, Fereddy Siagian, and Donna Sampaleng. "Hospitalitas Pendidikan Kristiani Dalam Masyarakat Majemuk." Jurnal Teologi Berita Hidup 3, no. 2 (2021): 328-339. 